\title{
Statistical analysis of trade relations of Romania with the EU member states
}

\author{
Harja Eugenia PHd, Vasile Alecsandri” University of Bacău, Romania \\ Stângaciu Oana Ancuţa PHd, Vasile Alecsandri” University of Bacău, Romania
}

\begin{abstract}
Summary
This study was done to analyse the structure in teritorial profile of the commercial relations of Romania compared to the European Union member states for year 2011. Based on the value of export and import trade flows for each EU member state with Romania and using statistical methods of analysis, there were subjected to processing existing information to determine the spatial distribution of foreign trade in the perspective of key trade partners Community market. As indicators such as trade balance and coverage of imports by exports is a proof to the effectiveness of trade relations between Romania and the EU Member States, there were also calculated the mentioned indicators for each Member State.
\end{abstract}

\section{Key words}

FOB export, CIF import, trade balance, coverage degree of imports with exports

\section{JEL Clasification}

C10, F10, F49, O11

\section{Introduction}

Trade, by its activities nature, is one of the most important sectors of a country or a community of countries, representing a main component in the commensurate level of development of a national economy. Meanwhile trade by its functions plays an important social role, as a point of contact between citizens and their local community, through which it circulates the latest information in terms of life styles, schemes and cultural activities.

The more developed a country is, the better the quality of life of people in that country, but none has all the material and human resources needed to ensure a good level of competence. This requires the development of exchanges with other countries: on the one hand to export goods that are in excess and in which production they are specialized, on the other hand to import products that are not available at all or in sufficient quantity.

Romania in the European Union has created new opportunities for economic development, but it also required the need to increase the competitiveness of the national products, without which we can not speak anymore about a positive development of the trade balance. Opening boarders for trade with goods among member States has raised a new problem concerning the collecting of the foreign trade data inside the member States, without which we could not know the existing situation in this area. Therefore they went to collecting statistical data concerning the intra-community statistical data trade directly from the operators who carry out these operations, throughout the INTRASTAT system. 


\section{FOB exports of Romania with the EU member states}

FOB exports of Romania with the EU member states in 2011 were 32.160 mil EURO, the main export states as destination, with a share of $5 \%$ of the total being: Germany -8.424 mil Euro, meaning $26,2 \%$ of total exports towards the comunity market; Italy -5.800 mil Euro $(18,0 \%$ of the total exports of the country), Hungary -2.568 mil Euro ( $8,0 \%$ of the total exports) and Bulgaria -1.636 mil Euro $(5,1 \%)$

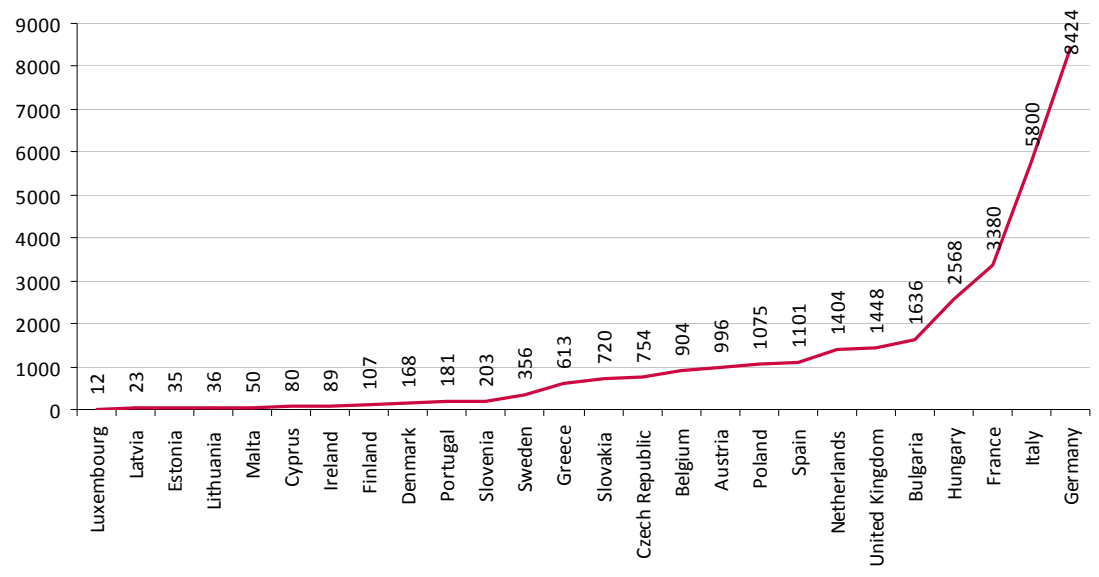

Figure 1. FOB exports of Romania with the EU member states in 2011 (mil. EURO) Source: processing by the TEMPO-Online

Other export markets of Romania that have a less share, between $1 \%$ and $3 \%$ of the total exports, are markets that have imported goods from Romania, of which value was between 0,3 and 0,9 bil Euro: Belgium - 904 mil Euro, meaning 2,8\% of the total exports towards the comunity market, the Czech Republic - 754 mil Euro, with 2,3\% of the total exports, Slovakia -720 mil Euro (2,2\% of the total exports), Greece - 613 mil Euro $(1,9 \%)$ and Sweden -356 mil Euro $(1,1 \%)$ and on the last places are states within a longer distance. They receive goods from Romania of a value less than 0,4 bil Euro: Luxembourg - 12 mil Euro ( $0,04 \%$ from the total exports), Lethon -23 mil Euro ( $0,07 \%$ of the total exports), Estonia - 35 mil Euro (0,11\%) and Lithuania - 36 mil Euro ( $0,11 \%)$

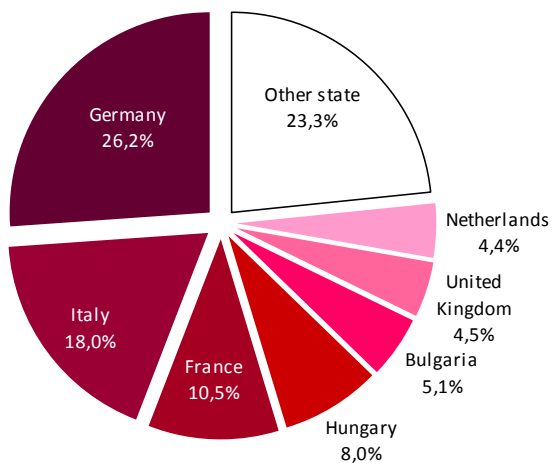

Figure 2. Structure of exports by EU countries in 2011 (\%)

Source: processing by the TEMPO-Online 


\section{CIF imports of Romania with the EU member States}

FOB imports of Romania with the EU member states in 2011 gathered 39.947 mil Euro, the main imports, with a share of over $5 \%$ of the total coming from Germany -9.405 mil Euro, meaning $23,5 \%$ of the total imports from the comunity market, Italy -6.251 mil Euro $(15,6 \%$ of total imports), Hungary - 4.783 mil Euro (12,0\%), France - 3.173 mil Euro ( 7,9\%) and Austria - 2.198 mil Euro( 5,5\%).

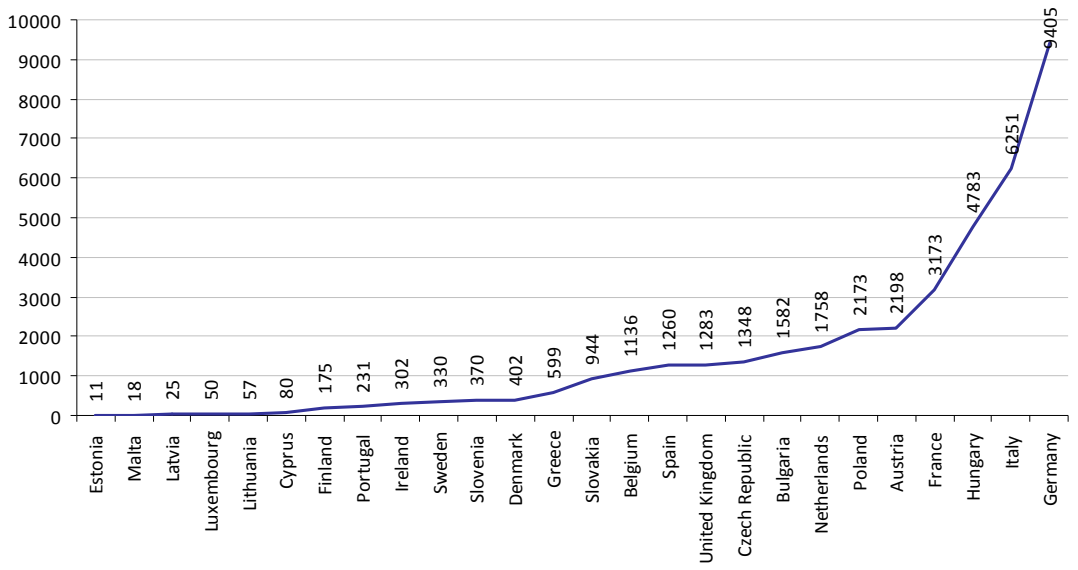

Figure 3. FOB imports of Romania with the EU member states in 2011 (mil. EURO) Source: processing by the TEMPO-Online

Other areas from where Romania imports goods have a less share, between $0,4 \%$ and $1,3 \%$ of the total, at the same time these states exported towards Romania goods having a value between 0,4 and 1,3 bil Euro: Spain - 1.260 mil Euro, meaning 3,2\% of the total imports from the comunity market, Belgium - 1.136 mil Euro ( 2,8\%), Slovakia - 944 mil. Euro $(2,4 \%)$, Greece - 599 mil Euro (1,5\%) and Denmark - 402 mil Euro (1,0\%). States that send goods to the Romanian market and have a value less than 0,5 bil Euro were: Esthonia - 11 mil Euro ( $0,03 \%$ of the total imports of Romania), Malta - 18 mil Euro ( $0,05 \%$ of total imports), Lethon - 25 mil Euro ( 0,06\%) and Luxembourg - 50 mil Euro ( 0,12\%), these holding the last places in the top.

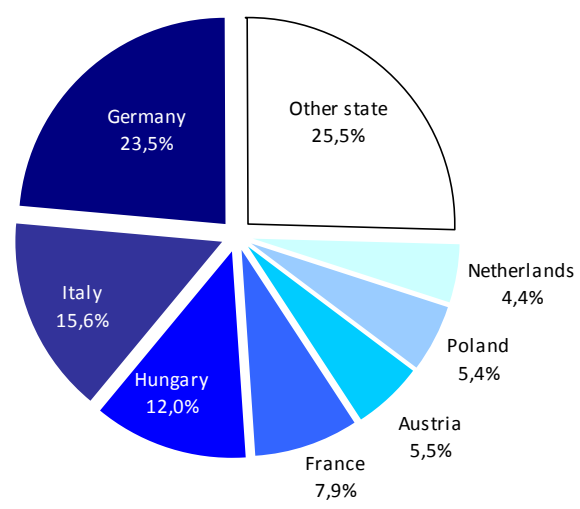

Figure 4. Structure of imports by EU countries in 2011 (\%) Source: processing by the TEMPO-Online 


\section{Trade balance and coverage degree of imports with exports by EU member states}

Export and import commercial flows of Romania with the EU member states are most highlighted in the trade balance, determining the external trade operations balance. The external trade balance FOB - CIF was to determine the differences between exports expressed in FOB prices and imports expressed in CIF.

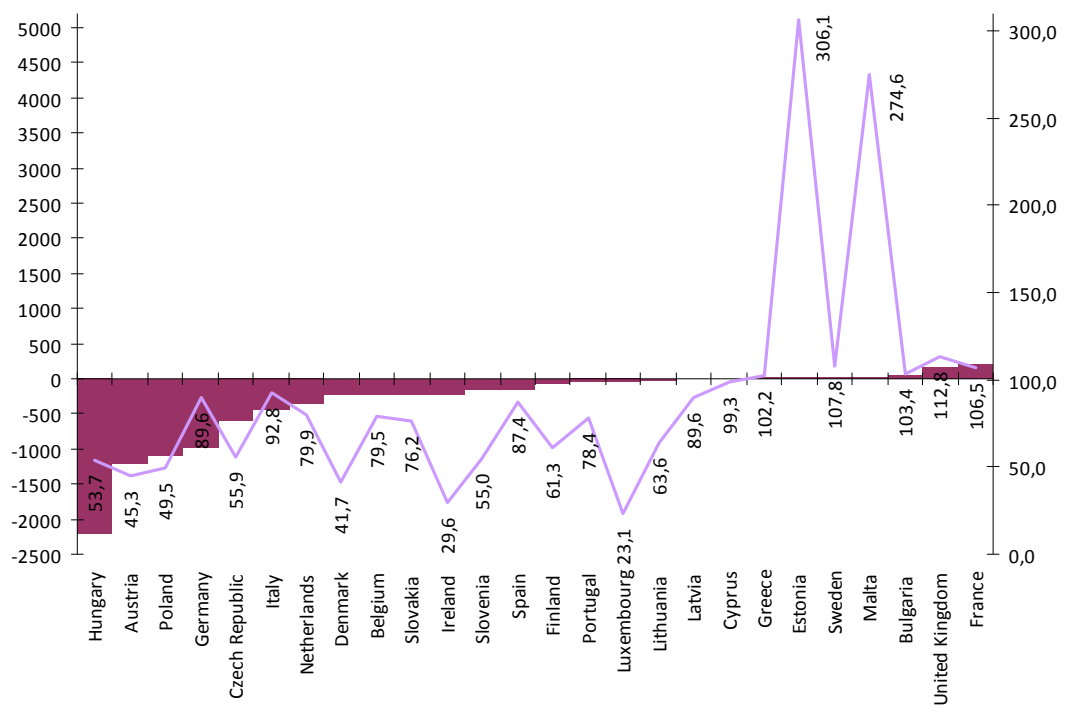

\section{Figure 5. International Trade Balance of FOB-CIF (million EUR) and FOB-CIF coverage (\%) in EU Member States in 2011 \\ Source: processing by the TEMPO-Online}

In 2011, in Romania there was a negative balance of the external commercial operations with the EU member states of 7.787 mil Euro. The highest negative balance is recorded in the commercial relations with Hungary ( -2.215 mil Euro), this being followed by the ones with: Austria ( -1.201 mil Euro), Poland ( -1.098 mil Euro) and Germany (-981 mil Euro). There can be seen that in the commercial trades with 7 of the $27 \mathrm{EU}$ member states, the value of exports was superior to imports, the highest surplus trade balance being recorded in the relations with France ( +260 mil Euro), followed by the United Kingdom $(+165$ mil Euro), Bulgaria (+54 mil Euro), Malta (+32 mil Euro), Sweden (+26 mil Euro), Esthonia (+23 mil Euro) and Greece ( +13 mil Euro ).

The coverage degree of imports with exports, as the trade balance, is an indicator that reflects the efficiency of international trades. In Romania, the coverage degree of imports with exports in 2011 was of $80,5 \%$. The lowest degrees were under $50 \%$ and were recorded in the trade relations with Luxembourg (23,1\%), Ireland (29,6\%), Denmark (41,7\%), Austria $(45,3 \%)$ and Poland $(49,5 \%)$. When speaking of commercial trades done with the main international trade partners of Romania, the imports are covered in a share of approximately $100 \%$. This way, for Italy, the value of the indicator is $92,8 \%$, while for Germany the calculated value is less than $89,6 \%$. On the first places of the top states with the highest coverage degree are Esthonia (306,1\%) and Malta (274,6\%), and at a higher distance is the United Kingdom (112,8\%), France (106,5\%), Bulgaria (103,4\%) and Greece (102,2\%) 


\section{Conclusion}

To sum up, even if Romania has trade relations with all EU member States, most of the international flows are based on some dominant trade partner countries. As geographical orientation, the main export destination countries, as well as areas of imports for Romania, in 2011, there were Germany, Italy, France and Hungary. It was remarked that in the trade relations with these four main partners, the imports are covered by exports, or in less extent, as the case of Hungary, either to an extent close to $100 \%$, under it - Germany and Italy and over it, France.

\section{Bibliography}

1. Harja E. (2009), Statistică, Ed. Matrix Rom, Bucureşti

2. Harja Eugenia, ,Evolution in the export of Romania 1991-2008”, Revista Română de Statistică, nr. $6 / 2009$

3. Harja Eugenia, Harja Monica, „Evolution in the trade balance of Romania during 1991-2008” "Annals of the University of Oradea"; Economic Science - Tom XVIII, 2009

4. Jaba E. (1998), Statistică, Ed. Economică, Bucureşti

5. Stângaciu O.A. (2010), Romania's foreign trade in 2008 - a territorial analysis, Studii și cercetări științifice - Seria: Științe Economice, Facultatea de Științe Economice, Universitatea Bacău, nr. 1 (15)

6. Stângaciu O.A. (2010), Romania's foreign trade with the European Union in 2008, Studii și cercetări științifice - Seria: Științe Economice, Facultatea de Științe Economice, Universitatea Bacău, nr. 1 (15)

7. Voineagu V. şi colaboratorii (2001), Statistică economică, Ed. Tribuna Economică, București

8. Colecţia Anuarul de comerţ exterior al României, Institutul Naţional de Statistică, Bucureşti

9. Colecţia Buletinul Statistic Lunar al judeţelor, Institutul Naţional de Statistică, Bucureşti

10. Baza de date proprii Direcţiei Județene de Statistică Bacău 